\title{
Evaluating Financial Performance of Saudi Listed Firms: Using Statistical Failure Prediction Models
}

Deena Saleh Merza Radhi

Ahlia University

Manama, Bahrain

Email: deena122@hotmail.com

*Corresponding author

\section{Adeal Sarea}

Ahlia University

Manama, Bahrain

Email: assarea@ahlia.edu.bh

\section{Received October, 2018; December, 2018}

\begin{abstract}
The study aims to compare the classification power of three statistical failure prediction models: Altman model 1968, Kida model, and Zmijewski. The purpose is to evaluate the financial performance of Saudi listed firms. The study sample consists of 122 listed industrial companies on the Saudi Stock Exchange for the period from 2014 to 2016. The results show that Zmijewski model is a more powerful tool in predicting the financial performance of Saudi listed firms than Altman model (1986), and Kida model. In addition, the results showthat there are statistical relationships between some ratios included in the three models and the financal performance of industrial companies, which was measured by EPS. The study recommended users of financial statements of Saudi listed companies use Zmijewski model, which performs well in evaluating their finacial position to be used when making the financial decisions.
\end{abstract}

Keywords: Statistical Failure Prediction Models; Evaluating Performance; Saudi Stock Market

Type: Research paper

This work is licensed under a Creative Commons Attribution 4.0 International License.

DOI: 10.51325/ijbeg.v2i1.20

\section{Introduction}

Financial default a global phenomenon that could occurs in developed countries and developing countries as well (Ijaz, 2013). It happens when the liabilities of a firm exceed its assets and generally happens due to the firm under capitalization, cash is not enough, resources of the firm where not capitalized properly, management inefficiency in firm's activities, decline of sales and negative market situation. Financial failure is a situation where is insufficient cash flow state and the company undertake severe losses without being insolvent (Opler \& Titman, 1994), (Purnanadam, 2008). Financial failure is a result of cumulative losses that causes disproportionate decrease in the asset values and increase in liabilities amounts. Financial failure occurs when the firm doesn't have the resources in order to fulfill the liabilities to the third party (Andrade \& Kaplan, 1998). 
Karels \& Prakash (1987) suggested that to explain financial failure a set of definitions has evolved. The set includes negative net worth, failure to pay to creditors, default on bonds, non payments of debts, bank accounts that over drawn, preferred dividends elimination, receivership, etc. Aharony, et al. (1980) explained financial failure as a signal of misallocating the resources which is unwanted from a social point of view. Gilbert et al. (1990) gave three most reasons for financial failure. They argued that the main factors influencing the probability of failure, it could be associated with the (1) Asset mix; (2) financial structure; and (3) corporate governance. The first cause of financial failure is the misallocation of assets. Assets are usually industry specific a firm may be driven to failure if they are not allocated efficiently. The resources mix between the long-term assets and short-term assets is important in an efficient market. Secondly, a firm's bankruptcy might be financial. The firm may have the right assets structure, but its financial structure is not appropriate leading to liquidity constraints. Thirdly, corporate governance may cause a firm into distress if conflicts of interest exist between the management and the stockholders.

Beaver (1966) conducted ratio analysis which makes the basis for the evolution of financial failure prediction models. The univariate model contributed to the development of multivariate model (Altman, 2000). Altman (1968) studied 22 common financial ratios to determine their predictive ability. Out of 22 ratios, Altman came up with five ratios as the most indicative of financial failure and used them to develop the financial failure prediction model. Altman model is a statistical model that managers, investors, shareholders, employees, and other stakeholders could apply to test company's financial position. The Altman model shows that whether a company is financially health, failed or in the grey zone. Then stakeholders can make the appropriate decisions. Edward Altman was finance Professor at New York University develop Altman's Z-score model in 1968 which became the most popular corporate failure prediction model. The model is used to assess the probability that a company will go insolvent. The model uses multivariate discriminant analysis (MDA) to develop a boundary line in a graph in such that if the company is to the left of that line, it is not likely to become failure whereas if it was to the right it is likely to go bankrupt (Altman 1968).

Another researcher developed other models to evaluate companies' financial position. For example, Kida in 1980 developed a model using discriminant analysis and factor analysis to 20 financial ratios to evaluate company's financial position. Functions of 5 ratios were selected by Kida to distinguish between healthy and non-healthy companies. In addition, Zmijewski (1984) used a probit analysis which is a type of regression analysis and projected 3 variables to predict company's financial position.

As an example of GCC country, the situation in Saudi remains questionable. The Saudi companies operate in an economy which is an oil based economy and a leading producer of oil and natural gas and one of the largest exporters of petrol and have played a leading role in OPEC. $87 \%$ of budget revenues come from petroleum sector, $42 \%$ of GDP and $90 \%$ of export earnings. $16 \%$ of the world petroleum reserves possessed KSA. The government continues to execute economic reforms and diversification, and especially since Saudi Arabia's accession to the WTO in 2005, and encourage foreign investment in 
the Kingdom. Growth of private sector is encouraged by the government in order to diversify the economy and to increase the employment of Saudi nationals. In April 2016, the government announced a set of socio-economic reforms known as Vision 2030.

Saudi has recently begun experiencing economic difficulties as a result of increasing oil prices. High oil prices influence the costs of other production and industrial and increase transport and other business costs. Ultimately, the high price of oil could affect the whole economy and, consequently, companies' activities, increasing the possibility of losses in Saudi. The real costs of failure are enormous and affect all stakeholders of the company (Altman 1984; Andrade \& Kaplan, 1998; Altman \& Hotchkiss, 2006; Outecheva, 2007; Opler\& Titman, 1994). The earlier the detection the better is the time allowed in making appropriate decisions and strategies (Outecheva 2007). Therefore, this study aims to evaluate the Saudi industrial listed companies' using statistical failure prediction models. The models used in the study include Altman (1968), Zmijewski (1984) and Kida (1980). In addition, it is important to choose the appropriate financial faulure model that fits the economy, and better indicate the real companies' finaical position.

\section{Literature review}

Gyimmah and Boachie (2018) studied the applicability of Altman's (2000) Z-score model in predicting corporate failure of listed firms in an emerging market within Ghana context. The study examined the model on fifteen companies listed on Ghana Stock Exchange (GSE) for 2013. The result shows that 66.7 percent of the listed companies were misclassified as failed firms (Type II Error) and properly classified 33.3 percent as nonfailed firms or safe zone firms. The study concludes that the Altman (2000) financial model is not applicable in Ghana because of high type II error rate and recommends more research for the use of non-financial models in predicting corporate failure in rising markets.

Januri et al., (2017) analyzed the differences of prediction results of 3 models of Altman Z-Score Model, Zmijewski Model and Springate Model for the companies in the cement industry that are listed in Indonesia Stock Exchange. Study population is all the cement companies that are listed in Indonesia stock exchange for the years 2011-2015 and the sample determined by purposive sampling method. kruskal-wallis difference test was the analytical method accuracy level and error type is to measure the accuracy. The study concluded that there are differences in potential bankruptcy between the three predictive models. And it is advisable to use another analysis models of predicting bankruptcy that have been found such as Shirata, Ohlson, CA Score, Fulmer etc.

Kheirabadiet al., (2016) looked at techniques that assess the financial performance and predict the financial crises and give the necessary warning to the companies can be useful. The study consists of 25 companies with financial health and 15 with financial crises within Tehran Stock exchange. Using Altman model to classify and predict company failure the study results showed that Altman model with an overall accuracy of 82.5 percent managed to classify companies correctly in groups of financial health and financial crises. 
Almansour (2015) studied 22 bankrupted and non-bankrupted companies listed at Jordanian Stock Exchange for the period from 2000 to 2003in order to predict financial failure model of an organization by using regression analysis. The results showed that ratios of working capital to total assets, current assets to current liabilities, market value of equity to book value of equity, retained earnings to total assets, and sales to total assets are significant and can be used as good indicator of probability of bankruptcy in Jordan.

Baniet al., (2014) conducted a study on forecasting of bank failures using Toffler and Zmiskey Models in Iran's banking industry. The study consist of 17 banks and private bank networks were studied and financial ratios where obtained for the years from 2008 to 2012. The results of the models were compared and analyzed. The results showed that the model Toffler was more conservative than the model Zmiskey to predict bankruptcy. Also bankruptcy prediction models are one of the tools that can be used by investors to make the decision whether to invest in a company or not.

Shanmugam and Mahalashmi (2014) studied if Altman model is applicable in predicting the corporate sickness among the Indian companies. The sample consist of 30 companies which is declared sick by Board for Industrial and Financial Reconstruction and 30 healthy companies for the period from 2007 to 2011. The results revealed that Altman model did not forecast failure among Indian companies. Also, ratio of failed companies that is properly classified is $83.33 \%$ in the second year prior to the bankruptcy.

Mohammed and Soon (2012) aimed to evaluate financial position of companies' using Altman financial distress prediction model and current ratio. 44 listed companies at Malaysia Stock Exchange companies were selected. The data used in the assessment was derived from financial statements of these companies. Results of the study indicated financial distress companies was listed in the board and not considered as PN17 Company. The study indicated that current ratio and Altman Z-score model are beneficial tools for stakeholders to forecast company's financial failure.

Alareeni and Branson (2013) studied the Altman model (1968) and the Altman model (1993) in Jordan. They have tested the models on 71 unhealthy companies and 71 healthy companies.

The result revealed that original model of Altman (1968) is working effectively. The zscore model is reliable for assessing failed companies in the industrial sector within Jordanian environment. For the service sector companies they found that z-score model couldn't give clear indicators in differentiating companies into failed and non-failed.

\section{Research Method}

\subsection{Data and sample size:}

The study sample consists of 122 industrial and service companies listed in Saudi Exchange excluding the financial institutions companies listed. The financial statement data of these 122 companies was extracted from Bloomberg database for the period from 2014 to 2016 to calculate the three statistical failure prediction models scores. As Bloomberg database is one of the best database providers in all over the world. 


\subsection{Methodology:}

The methodology followed in the study contain calculating value of Z-score of Altman model for each company for the years from 2014 to 2016, then classifying each firm into one of the three zones depending on the cut-off points of each zone provided by the Altman Z-score model, namely failed, non-failed and grey zone. The Z-scores values were calculated for each firm using Altman's coefficients from the equation presented below.

This is applied to the two other models, Kida and Zmijewski Models. Microsoft Excel program was used to calculate and analyze the results of the three models and getting the results.

The other part of the study is to measure if Zmijewski model $\mathrm{z}$ score ratios of Zmijewski have an effect on the company performance measured by EPS. Descriptive statistics, correlation and regression analysis is calculated using SPSS program.

\subsection{Study variables:}

- Earnings per share: is used as a dependent variable. EPS is classified as dependent variable in measuring correlation between Zmijewski model variables.

- Altman z score ratios, Kida score ratios and Zemijiwski score ratios are used as independent variables in regression analysis to measure classification power of these models.

\subsection{Research model}

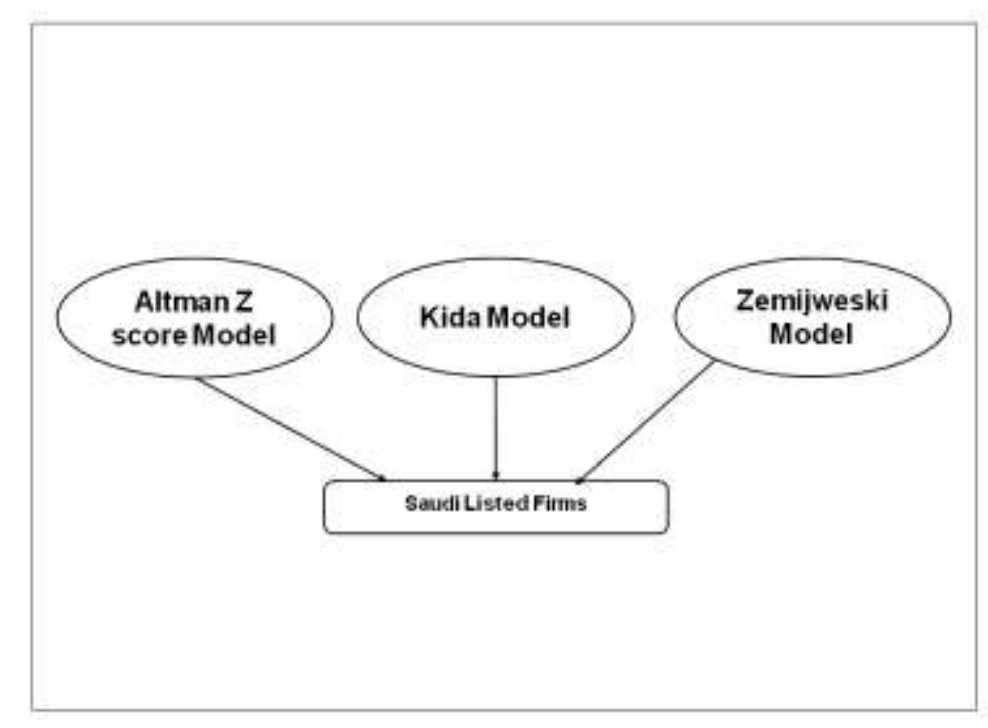

Figure 1: Models used to evaluate the companies position in Saudi Arabia 


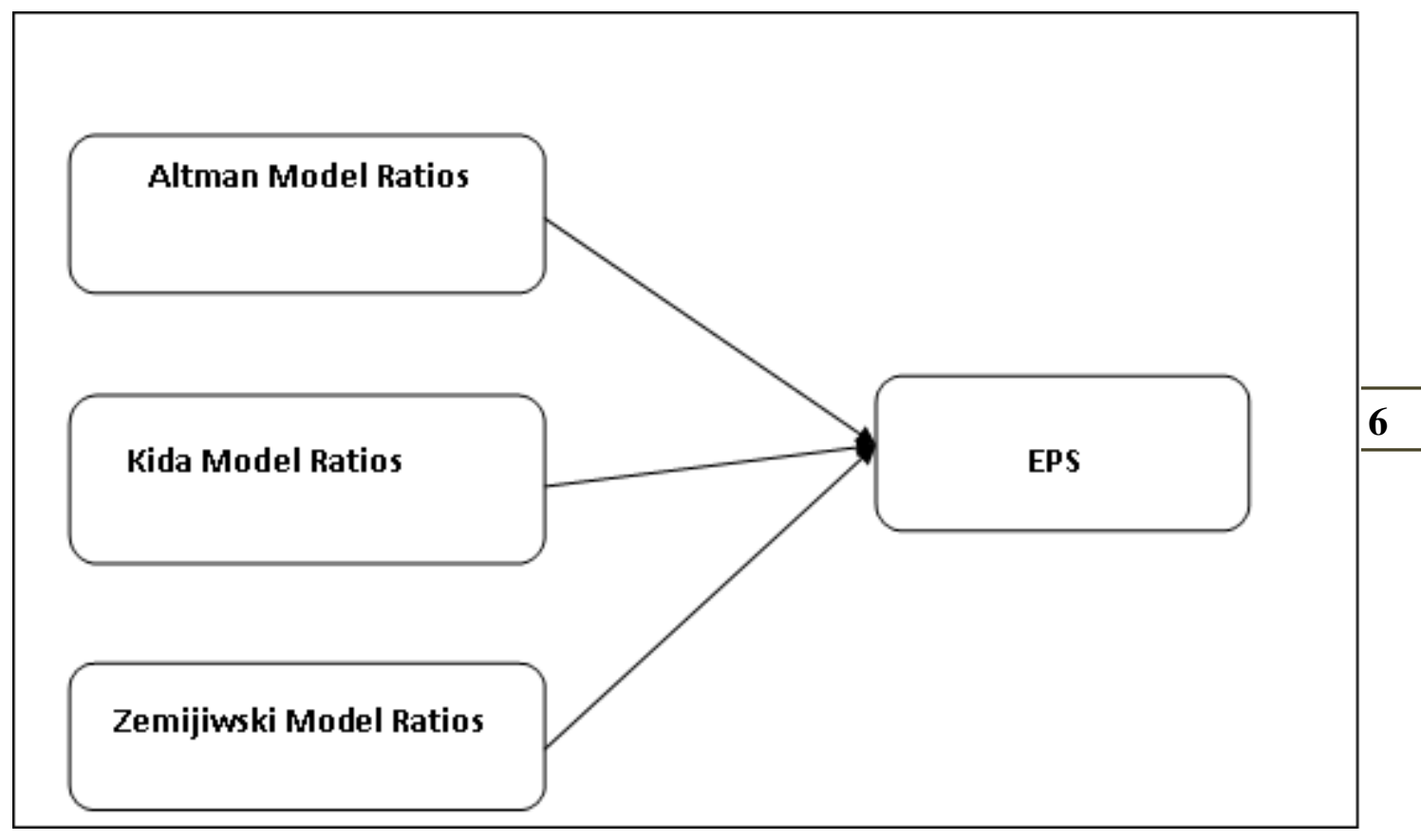

Figure 2: Independent variables (Fianical ratios) and the dependent variable (EPS)

\section{Statistical Techniques Used In The Study}

The statistical failure prediction models used in this study were calculated using Excel program. Descriptive statistics was applied such as mean, standard deviation, minimum and maximum values. Moreover, correlation and regression analysis were employed in testing hypothesis of the study and to measure the Altman z score ratios, Kida model ratios and Zemijiwski model ratio on EPS. The Software's used to perform all statistics were SPSS and MS Excel.

\subsection{Altman Z-Score Model:}

$$
\mathrm{Z}=0.012 X_{1}+0.014 X_{2}+0.033 X_{3}+0.006 X_{4}+0.999 X_{5}
$$

Where:

$\mathrm{X}_{1}=$ Working Capital/Total Assets

$\mathrm{X}_{2}=$ Retained Earnings/Total Assets

$\mathrm{X}_{3}=\mathrm{EBIT} / \mathrm{Total}$ Assets

$\mathrm{X}_{4}=$ Market Value Equity/Book Value of Total Debt

$\mathrm{X}_{5}=$ Sales/Total Assets

\section{Cutoff points:}

- If $Z<1.80 \rightarrow$ Distress Zone.

- If $Z>2.99 \rightarrow$ Safe Zone.

- If $1.8<Z<2.99 \rightarrow$ Grey Zone. 


\subsection{Kida Model:}

$$
Z=1.042 X_{1}+0.42 X_{2}+0.461 X_{3}+0.463 X_{4}+0.271 X_{5}
$$

Where:

$\mathrm{Z}=$ weighted average of five separate ratios

$\mathrm{X}_{1}=$ net profit after tax / the total assets

$\mathrm{X}_{2}=$ net worth/total debt

$\mathrm{X}_{3}=($ Accounts and Notes Payable / total sales $)$

$\mathrm{X}_{4}=$ Sales $/$ total assets

$\mathrm{X}_{5}=$ Cash $/$ total assets

\section{Cutoff points:}

- $Z>0.38$ are considered financially healthy

- $\mathrm{Z}<0.38$ are considered financially unhealthy and may go bankrupt

\subsection{Zmijewski Model:}

$$
\mathrm{Z}=-4.3-4.5 \mathrm{X}_{1}+5.7 \mathrm{X}_{2}-0.004 \mathrm{X}_{3}
$$

Where:

$$
\begin{aligned}
& \mathrm{X}_{1}=\text { net income/total asset } \\
& \mathrm{X}_{2}=\text { total liabilities/total assets } \\
& \mathrm{X}_{3}=\text { current asset/current liabilities }
\end{aligned}
$$

\section{Cut of points:}

- $Z>0.5$ is considered financially healthy.

- $\mathrm{Z}<0.5$ is considered financially unhealthy and may go bankrupt.

\section{Analysis and results}

This section shows descriptive statistics and correlation of Altman model, Kida Model and Zimijwski model and the regression analysis of the three models.

\subsection{Altman Model Statistics}

\subsubsection{Descriptive statistics}

Descriptive statistics shows minimum, maximum, mean and standard deviation of dependent and independent variables. Table (1) shows descriptive statistics of Altman model. X1 (working capital/total assets) range from -.7775 to .6566 with a mean of .128982 and standard deviation of .1915.X2 (retained earnings/total assets) range from 1.8995 to .5512 with a mean of .067991 and standard deviation of .252. X3 ranges from .5095 to .3621 with a mean of .064909 and standard deviation of .086. X4 (market value equity/book value of total debt) ranges from .0000 to 70.5223 with a mean of 6.5113 and standard deviation of 8.583 . X5 (sales/total assets) range from .0000 to 4.4677 with a 
mean of .587089 and standard deviation of .562. EPS range from -35.5725 to 9.2900 with a mean of 1.645855 and standard deviation of 3.219 .

Table 1: Altman Z-score Model Descriptive Statistics

\begin{tabular}{|l|c|c|c|c|}
\hline & Minimum & Maximum & Mean & Std. Deviation \\
\hline $\mathrm{X} 1$ & -.7775 & .6566 & .128982 & .1915034 \\
\hline $\mathrm{X} 2$ & -1.8995 & .5512 & .067991 & .2515276 \\
\hline $\mathrm{X} 3$ & -.5095 & .3621 & .064909 & .0864701 \\
\hline $\mathrm{X} 4$ & .0000 & 70.5223 & 6.511368 & 8.5832457 \\
\hline $\mathrm{X} 5$ & .0000 & 4.4677 & .587089 & .5616386 \\
\hline $\mathrm{EPS}$ & -35.5725 & 9.2900 & 1.645855 & 3.2194578 \\
\hline
\end{tabular}

Where X1 = working capital/total assets, $\mathrm{X} 2=$ retained Earnings/total Assets, $\mathrm{X} 3=\mathrm{EBIT} /$ total assets, $\mathrm{X} 4=$ (market value equity/book value of total debt), X5= (sales/total assets) are independent variables and EPS (dependent variable).

\subsection{Kida model statistics}

\subsubsection{Descriptive Statistics}

Descriptive statistics shows minimum, maximum, mean and standard deviation of dependent and independent variables. Table 2 shows that X1 (net profit after tax / the total assets) ranges from -.5100 to .3800 with a mean of .060967 and standard deviation of .0880. X2 (interest and expenses discounted for short-term and long-term obligations) ranges from .0000 to 430.2000 with a mean of 11.097238 and standard deviation of 42.582. X3 ((Accounts and Notes Payable / total sales) *12) ranges from .0000 to 19.8300 with a mean of 1.6138 and standard deviation of 2.719. X4 (sales / total assets) ranges from .0000 to 4.4700 with a mean of .587 and standard deviation of .561. X5 (cash / total assets) ranges from .0000 to .4000 with a mean of .065608 and standard deviation of 0.065. EPS range from -35.57 to 9.29 with a mean of 1.6413 and standard deviation of 3.21615 .

Table 2: Kida model descriptive Statistics

\begin{tabular}{|l|c|c|c|c|}
\hline & Minimum & Maximum & Mean & Std. Deviation \\
\hline X1 & -.5100 & .3800 & .060967 & .0880815 \\
\hline X2 & .0000 & 430.2000 & 11.097238 & 42.5805391 \\
\hline X3 & .0000 & 19.8300 & 1.613812 & 2.7191074 \\
\hline X4 & .0000 & 4.4700 & .587044 & .5614370 \\
\hline E5 & .0000 & .4000 & .065608 & .0648569 \\
\hline
\end{tabular}

Where $\mathrm{X} 1=$ (net profit after tax $/$ the total assets), $\mathrm{X} 2=$ net worth/total debt, $\mathrm{X} 3=(($ Accounts and Notes Payable / total sales $) * 12), \mathrm{X} 4=($ sales $/$ total assets $), \mathrm{X} 5=($ cash / total assets $)$ are independent variables and EPS (dependent variable). 


\subsection{Zmijewski Model statistics}

\subsubsection{Decriptive Statistics}

In Table 3, descriptive statistics shows minimum, maximum, mean and standard deviation of dependent and independent variables.

Table 3: Zmijewski Modeldescriptive Statistics

\begin{tabular}{|l|c|c|c|c|}
\hline & Minimum & Maximum & Mean & Std. Deviation \\
\hline X1 & -2.3000 & 1.7000 & .273967 & .3959501 \\
\hline X2 & .0000 & 5.4700 & 2.284160 & 1.1793982 \\
\hline EPS & .0000 & .0600 & .009091 & .0091940 \\
\hline
\end{tabular}

Where $\mathrm{X} 1=$ net income/total asset, $\mathrm{X} 2=$ total liabilities/total assets, $\mathrm{X} 3=$ current asset/current liabilities are independent variables and EPS (dependent variable).

\subsection{Regression analysis of Altman model, Kida model and Zmijewski model}

The Multiple Linear Regression Model "Panel Regression Model" was used to the three models to compare the classification power of Altman model, Kida model and Zimijewski model.

Table 4: Panel Regression Models

\begin{tabular}{|c|c|c|c|c|c|c|}
\hline \multirow{2}{*}{ Variables } & \multicolumn{2}{|c|}{ Altman Model } & \multicolumn{2}{|c|}{ Kida Model } & \multicolumn{2}{|c|}{ Zmijewski Model } \\
\hline & $\beta$ & $t$-Statistic & $\beta$ & $t$-Statistic & $\beta$ & $t$-Statistic \\
\hline Constant & -1.600 & $\begin{array}{c}-6.622 * * * \\
0.0000\end{array}$ & -0.7883 & $\begin{array}{c}-3.9929 * * * \\
0.0001\end{array}$ & -1.6598 & $\begin{array}{c}-2.8240 * * * \\
(0.0052)\end{array}$ \\
\hline \multicolumn{7}{|c|}{$\begin{array}{c}\text { Independent } \\
\text { Variables: }\end{array}$} \\
\hline $\mathrm{X} 1$ & 3.0204 & $\begin{array}{l}2.2947 * * \\
(0.0226)\end{array}$ & 33.805 & $\begin{array}{c}29.434 * * * \\
(0.0000)\end{array}$ & 8.4946 & $\begin{array}{c}22.9766^{* * * *} \\
0.0000\end{array}$ \\
\hline $\mathrm{X} 2$ & 4.4898 & $\begin{array}{l}3.3064 * * \\
(0.0011)\end{array}$ & 0.0056 & $\begin{array}{l}2.3309 * * \\
(0.0052)\end{array}$ & 0.2955 & $\begin{array}{c}1.3288 \\
(0.0000)^{* * *}\end{array}$ \\
\hline X3 & 40.862 & $\begin{array}{c}3.3064 * * * \\
(0.0000)\end{array}$ & 0.0875 & $\begin{array}{c}2.3309 * * \\
(0.0203)\end{array}$ & 38.3422 & $\begin{array}{c}1.7589 \\
(0.0099)^{* * *}\end{array}$ \\
\hline $\mathrm{X} 4$ & -0.084 & $\begin{array}{c}-3.7032 * * * \\
(0.0003)\end{array}$ & 0.3909 & $\begin{array}{c}2.1260 \\
(0.0342)^{* *}\end{array}$ & & \\
\hline X5 & 0.871 & $\begin{array}{l}2.9776 * * \\
(0.0032)\end{array}$ & -0.3610 & $\begin{array}{l}-0.2640 \\
(0.7919) \\
\end{array}$ & & \\
\hline$\overline{\mathrm{R}^{2}}$ & 0.926 & & 0.733 & & 0.972 & \\
\hline $\begin{array}{l}\text { Adjusted } \\
\mathrm{R}^{2}\end{array}$ & 0.886 & & 0.729 & & 0.976 & \\
\hline F-Statistic & $23.25 * * *$ & & $198.130 * * *$ & & $48.344 * * *$ & \\
\hline \multicolumn{7}{|c|}{ Hausman Test: } \\
\hline Chi-Sq. & 1.062 & & 0.765 & & 1.109 & \\
\hline
\end{tabular}


Where Altman model X1= working capital/total assets, $\mathrm{X} 2=$ retained Earnings/total Assets, $\mathrm{X} 3=\mathrm{EBIT} /$ total assets, $\mathrm{X} 4=$ (market value equity/book value of total debt), X5 $=$ (sales/total assets) are independent variables and EPS (dependent variable). Kida model Where $\mathrm{X} 1=$ (net profit after tax $/$ the total assets), $\mathrm{X} 2=$ (interest and expenses discounted for short-term and long-term obligations), X3 = ((Accounts and Notes Payable / total sales)*12), X4 = (sales / total assets), $\mathrm{X} 5=($ cash / total assets) are independent variables and EPS (dependent variable). Zmijewski model Where X1=net income/total asset, $\mathrm{X} 2=$ total liabilities/total assets, $\mathrm{X} 3=$ current asset/current liabilities are independent variables and EPS (dependent variable).

To summarize table (4) shows that the best model among the three models is the third model "Zmijewski Model" where the R-Square and Adjusted R-Square of Zmijewski Model is larger than Altman Model and Kida Model. Hausman test shows that its value of Zmijewski Model (1.109) is larger than Altman Model and Kida Model (1.062 and 0.765 respectively) which indicates that Zmijewski Model is most effective in KSA Economy.

\subsection{The application results of the three models :}

\subsubsection{Altman Z-score Model:}

Table 5 presents the results of Altman Z score model for Saudi listed firms for the years 2014, 2015 and 2016. As can be seen from table below in 2014 the percentage of failed companies is of $20 \%$, increased to $24 \%$ in 2015 and reached to $31 \%$ in the year 2016. The percentage of non-failed companies is $60 \%$ in 2014, decreased to $52 \%$ in 2015 reached to $47 \%$ in 2016 . The model could not classify $20 \%$ of firms in 2014 and increased to $25 \%$ of firms in 2015 and reached to $22 \%$ of firms in 2016. Given the evaluation selection criterion mentioned above, this model results reflect that the Altman model classification power is week in the Saudi stock exchange. The model could not reflect the real position of listed companies in the stock market. The percentage of companies which are classified as failed companies is slightly high (e.g. 20\% in the year 2014, 24\% in the year 2015, and $31 \%$ in the year 2016). Moreover, the model failed to classify the financial position of a set of companies in the study period, as mentioned in table 5. Namely, it can be seen that a high number of companies are classified in the gray area (25 companies of the year 2014, 30 companies of the year 2015 and 27 companies of the year 2016), which means also the classification power of the model is relatively low. Further, the model classification percentage of companies as non-failed is not more than $60 \%$, which is considered very low compared to the prior study such as (Alareeni, 2013).

Table 5. Results of Altman model, Kida Model and Zemjweski model

\begin{tabular}{|c|c|c|c|c|c|c|c|}
\hline \multirow{2}{*}{ Year } & \multicolumn{3}{|c|}{ Classification of Altman Z-score } & \multicolumn{2}{c|}{$\begin{array}{c}\text { Classification of Kida } \\
\text { Model }\end{array}$} & \multicolumn{2}{c|}{$\begin{array}{c}\text { Zlassification of } \\
\text { Zimejwski Model }\end{array}$} \\
\cline { 2 - 8 } & $\mathrm{Z}<1.81$ & $1.81<\mathrm{Z}<2.67$ & $\mathrm{Z}>2.67$ & $\mathrm{Z}<0.38$ & $\mathrm{Z}>0.38$ & $\mathrm{Z}>.5$ & $\mathrm{Z}<.5$ \\
\cline { 2 - 8 } & Failed & Gray Area & Non failed & Failed & Non failed & Failed & Non failed \\
\hline 2014 & $24(20 \%)$ & $25(20 \%)$ & $73(60 \%)$ & $7(6 \%)$ & $115(94 \%)$ & $2(2 \%)$ & $120(98 \%)$ \\
\hline 2015 & $29(24 \%)$ & $30(25 \%)$ & $63(52 \%)$ & $9(7 \%)$ & $113(93 \%)$ & $3(2.4 \%)$ & $119(97.6 \%)$ \\
\hline 2016 & $38(31 \%)$ & $27(22 \%)$ & $57(47 \%)$ & $22(18 \%)$ & $100(82 \%)$ & $8(7 \%)$ & $1143 \%)$ \\
\hline
\end{tabular}




\subsubsection{Kida Model Results:}

The application results of Kida model for Saudi listed firms for the years 2014, 2015 and 2016 are presented in Table 5. In 2014 the percentage of firms classified as failed companies is $6 \%$, increased by $1 \%$ in 2015 and reached to $18 \%$ in 2016 . The percentage of firms classified as non-failed was $94 \%$ in 2014 and decreased by $1 \%$ in 2015 , and decreased to $82 \%$ in 2016 . This result clearly indicates that Kida model well classified companies' financial position in Saudi stock exchange. In general, the percentage of firms classified as failed companies is very low for the first two years (2014 and 2015), but becomes high in the year 2016 (6\%, 7\% and 18\% for the three years respectively). In spite of that Altman model is the most commonly used model in all over the world, when the Kida model is compared to the Altman model, Kida model performs better in classifying the companies as non-failed through all the three years. This indicates that Kida model is valid for Saudi listed firms and better than Altman model in classifying financial positions of companies listed at Saudi Stock Exchange. But taking into consideration the high percentage of failed companies classified by Kida model in the year 2016, the model cannot be considered as the best in evaluating the financial position of companies listed in Saudi Stock Exchange.

\subsubsection{Zemijiwski Model Results:}

Table 5 presents the results of Zimijiewski model for Saudi listed firms for the years 2014, 2015 and 2016. In 2014 the percentage of failed firms was $2 \%$ and the percentage slightly increased to $2.4 \%$ in 2015 . In 2016, the percentage of failed companies reached to $7 \%$. Table 5 shows also that the percentage of non-failed companies was $98 \%$ in 2014 and $97.60 \%$ in 2015 . In 2016, the percentage of non-failed companies decreased by $5 \%$ reaching 93\%. Hence, the Zimijiewski model classification percentages for all years from 2014 to 2016 are higher than the two models' classification percentages (Altman and Kida). The model could correctly classify the companies as non-failed companies with high percentages in all the three years as shown in table 5 (98\%, 97.60 and 93\%). Thus, the classification rate of Zemijiwski Model is considered very high compared to the other two models and even to the previous studies that used the statistical failure prediction models (e.g., Alareeni, 2013). Therefore, this result reflects that Zemijiwski model well fit and valid for the Saudi Stock Exchange and can best evaluate financial position of companies listed at Saudi Stock Exchange.

To concluded, the objective of the study is to evaluate three statistical failure prediction models using Saudi listed firms. These models are Altman Z-score model, Kida model and Zimijiweski. Altman $\mathrm{Z}$ score model generates the highest percentage of failed firms for the three years $20 \%$ in 2014, 24\% in 2015 and 31\% in 2016. Kida Model comes in the second place with the percentages of $6 \%, 7 \%$ and $18 \%$ for the years 2014, 2015 and 2016, respectively. Zimijewski come in the third place with the lowest percentage of failed firms, 2\%, 2.4\% and 7\% for the years 2014, 2015 and 2016, respectively. In other words, 
the Zimijewski model could correctly classify the real position of companies listed in Saudi Stock Market.

Given that GCC countries have the same economic environments and they share many economic similarities, the results of this study motives to use Zimijewski model in classifying the companies' position in the other GCC countries. The statistical prediction model users can benefit from this model in evaluating companies' position and making investment decisions.

These findings differs with (Chadha 2016) that founded that Altman model contradict with Zimijewski model for Kuwait stock Exchange. As Altman model classify $27.04 \%$ and $28.06 \%$ as failed in 2013 and 2014 while Zimijewski model classifies $76.53 \%$ and $75.51 \%$ as failed firms for the same period.

\section{Conclusion and Recommendations}

\subsection{Conclusion}

The aim of the study is to evaluate the classification power of Altman Z score model, kida Model and Zemijweski model in predicting financial failure of Saudi listed companies at Saudi stock exchange and to examine the association of these models ratios with EPS. The results showed that Zemijweski model have the highest classification rate in predicting financial failure of Saudi listed companies than Altman z score model and Kida model. The model classify that $2 \%, 2.4 \%$ and $7 \%$ as failed companies for the years 2014, 2015 and 2016 respectively which was the lowest percentage compared with Altman z score model and Kida model. Regression analysis results agrees with finding thus is the model generates $97.2 \%$ in $\mathrm{R}^{2}$ compared to $92.6 \%, 73.3 \%$ for Altman $\mathrm{z}$ score model and Kida models. In addition statistical results showed that significant positive relationship between EPS and Zemijweski model ratios for X1, X2 and X3.

Altman z score model classifies that 20\%,24\% and $31 \%$ as failed companies for the years 2014, 2015 and 2016 respectively as failed companies. In addition statistical results showed that significant positive relationship between EPS and Altman $\mathrm{Z}$ score model ratios for $\mathrm{X} 1, \mathrm{X} 2, \mathrm{X} 3$ and $\mathrm{X} 5$ except for $\mathrm{X} 4$ has negative significant relationship.

Kida Model classifies that $6 \%, 7 \%$ and $18 \%$ as failed companies for the years 2014, 2015 and 2016 respectively as failed companies. Moreover statistical results showed that significant positive relationship between EPS and Altman Z score model ratios for X1, $\mathrm{X} 2, \mathrm{X} 3$ and X4 except for X5 has insignificant relationship with EPS.

The results showed that all Altman $\mathrm{z}$ score model ratios are correlated with EPS.X1, $\mathrm{X} 2, \mathrm{X} 3, \mathrm{X} 5$ are significant positive correlated and $\mathrm{X} 4$ is negatively correlated independent.

Kida model ratios are positively correlated with EPS except for X5 is insignificant.

The results highlighted that all Zemijweski model ratios are correlated with EPS. X1, X2 and $\mathrm{X} 3$.

In 2016, all the three models showed substantial increase in the percentage of failed companies compared to 2015. An increase of 7\%, $11 \%$ and $5 \%$ in failed companies recorded by Altman z score, Kida model and Zemijweski model respectively. This 
increase was because of increase of energy prices and oil by government of Saudi Arabia which leads to higher cost of production and delivery to companies. The other reasons were decrease of spending of government and stop of some projects. In addition, lower the demand of luxurious goods and floating of Egyptian pound.

\subsection{Recommendations}

There are different models to financially assess the status of a firm. As seen in the literature Altman Z score Altman's model is most widely used model to measure the financially distressed companies and the researcher recommends use of other models to determine the financial distressed companies. This can even expand the number of distressed companies in a given Securities Exchange. It is recommended to investors, managers and other stakeholder in Saudi Arabia and other GCC countries as they have similar economic conditions to use the Zmijewski failure prediction models as an assessment tool for potential investment in companies in Saudi Stock Market. The study also recommends regulators; investors as well as management of an organization to continuous calculate different statistical financial failure models because of the continuous change of economic factors. The study recommends along with the failure prediction model should use the prevailing Economic conditions such as changes in the interest rates, inflation to predict the position of the company in the economy.

\section{References}

Adam, M. H. M. (2014). Evaluating the financial performance of banks using financial ratios-a case study of Erbil Bank for investment and finance. European Journal of Accounting Auditing and Finance Research, 2(2), 156-170.

Aharony, J., Jones, C. P., \&Swary, I. (1980). An analysis of risk and return characteristics of corporate bankruptcy using capital market data. The Journal of Finance, 35(4), 1001-1016. https://doi.org/10.1111/j.1540-6261.1980.tb03516.x

Al Karim, R., \&Alam, T. (2013). An evaluation of financial performance of private commercial banks in Bangladesh: Ratio analysis. Journal of Business Studies Quarterly, 5(2), 65.

Alareeni, B. (2019). A Review of Auditors' GCOs, statistical prediction models and artificial intelligence technology. International Journal of Business Ethics and Governance, 2(1), 19-31. https://doi.org/10.51325/ijbeg.v2i1.30

Alareeni, B. and Alqallaf, H. (2018). Evolving of selected integrated reporting capitals among listed Bahraini Banks. International Journal of Business Ethics and Governance, 1(1), 15-36. https://doi.org/10.51325/ijbeg.v1i1.10

Alareeni, B. (2018). Does corporate governance influence earnings management in listed companies in Bahrain Bourse?. Journal of Asia Business Studies, 12(4), 551-570. https://doi.org/10.1108/JABS-06-2017-0082

Alareeni, B., \& Branson, J. (2013). Predicting listed companies' failure in Jordan using Altman models: A case study. International Journal of Business and Management, 8(1), 113. https://doi.org/10.5539/ijbm.v8n1p113 
Alifiah, M. N., Salamudin, N., \& Ahmad, I. (2013). Prediction of financial distress companies in the consumer products sector in Malaysia. Jurnal Teknologi, 64(1), 8591. https://doi.org/10.11113/jt.v64.1181

Al-Kassar, T. A., \& Soileau, J. S. (2014). Financial performance evaluation and bankruptcy prediction (failure). Arab Economic and Business Journal, 9(2), 147-155. https://doi.org/10.1016/j.aebj.2014.05.010

Alkhatib, K., \& Al Bzour, A. E. (2011). Predicting corporate bankruptcy of Jordanian listed companies: Using Altman and Kida models. International Journal of Business and Management, 6(3), 208. https://doi.org/10.5539/ijbm.v6n3p208

Almansour, B. Y. (2015). Empirical model for predicting financial failure. American Journal Of Economics, Finance And Management, 1(3), 113-124.

Altman, E. I. (1968). Financial ratios, discriminant analysis and the prediction of corporate bankruptcy. The journal of finance, 23(4), 589-609. https://doi.org/10.1111/j.15406261.1968.tb00843.x

Altman, E. I. (2000). Predicting financial distress of companies: revisiting the Z-score and ZETA models. Stern School of Business, New York University, 9-12.

Altman, E. I., \& Hotchkiss, E. (2006). Corporate Credit Scoring-Insolvency Risk Models, in Corporate Financial Distress and Bankruptcy. https://doi.org/10.1002/9781118267806

Andrade, G., \& Kaplan, S. N. (1998). How costly is financial (not economic) distress? Evidence from highly leveraged transactions that became distressed. The Journal of Finance, 53(5), 1443-1493. https://doi.org/10.1111/0022-1082.00062

Bani, M., Zadehbagher, M., Jalili, J., \&Saberimanesh, M. A. (2014). Prediction of Bank failures based on Zmisky and Toffler Models in the Banking industry of Iran. Kuwait Chapter of the Arabian Journal of Business and Management Review, 3(12), 142. https://doi.org/10.12816/0018813

Beaver, W. H. (1966). Financial ratios as predictors of failure. Journal of accounting research, 71-111. https://doi.org/10.2307/2490171

Bhunia, A., \& Sarkar, R. (2011). A study of financial distress based on MDA. Journal of Management Research, 3(2), 1. https://doi.org/10.5296/jmr.v3i2.549

Central Intelligence agency https://www.cia.gov./library/publication/the-worldfactbook/geos/sa.htm

Chadha, P. (2016). Financial Performance of Companies listed on the Kuwait Stock Exchange. An Exploration using Altman's Z-Score Model. Anchor Academic Publishing. https://doi.org/10.4172/2162-6359.1000341

Chancharat, N., Davy, P., \& McCrae, M. (2007). Examining Financially Distressed Company in Australia: The Application of Survival Analysis. In EABR (Business \& ETLC (teaching) Conference Proceedings.

Gilbert, L. R., Menon, K., \& Schwartz, K. B. (1990). Predicting bankruptcy for companies in financial distress. Journal of Business Finance \& Accounting, 17(1), 161-171. https://doi.org/10.1111/j.1468-5957.1990.tb00555.x

Grammatikos, T. H. E. O. H. A. R. R. Y., \&Gloubos, G. E. O. R. G. E. (1984). Predicting bankruptcy of industrial companies in Greece. Spoudai, 33, 3-4.

Grünberg, M., \&Lukason, O. (2014). Predicting bankruptcy of industrial companies. International Journal of Trade, Economics and Finance, 5(1), 93. https://doi.org/10.7763/IJTEF.2014.V5.347

Ijaz, M. S., Hunjra, A. I., Hameed, Z., \&Maqbool, A. (2013). Assessing the financial failure using Z-Score and current ratio: A case of sugar sector listed companies of Karachi Stock Exchange. 
Januri Januri, S. E., \& MM, M. S. (2018). The Analysis of the Bankruptey Potential Comparative by Altman Z-Score, Springate and Zmijewski Methods at Cement Companies Listed in Indonesia Stock Exchange. KUMPULAN JURNAL DOSEN UNIVERSITAS MUHAMMADIYAH SUMATERA UTARA.

Ježovita, A. (2015). Designing the model for evaluating business quality in Croatia. Management: journal of contemporary management issues, 20(1), 101-129.

Karels, G. V., \& Prakash, A. J. (1987). Multivariate normality and forecasting of business bankruptcy. Journal of Business Finance \& Accounting, 14(4), 573-593. https://doi.org/10.1111/j.1468-5957.1987.tb00113.x

Kheirabadi, H. S., Nezhad, M. B., \&Azhdar, M. (2016). Financial performance evaluation and prediction of the financial crisis on companies listed on the Tehran Stock Exchange. International Business Management, 10(19), 4549-4555.

L Bani, M., Zadehbagher, M., Jalili, J., \&Saberimanesh, M. A. (2014). Prediction of Bank failures based on Zmisky and Toffler Models in the Banking Industry of Iran. Kuwait Chapter of Arabian Journal of Business and Management Review, 3(12), 142-152. https://doi.org/10.12816/0018813

Lakshan, A. M. I., \&Wijekoon, W. M. H. N. (2013). The use of financial ratios in predicting corporate failure in Sri Lanka. GSTF Business Review (GBR), 2(4), 37.

Mahama, M. (2015). Assessing the state of financial distress in listed companies in Ghana: Signs, sources, detection and elimination-A Test of Altman's Z-Score.

Mohammed, A. A. E., \& Kim-Soon, N. (2012). Using Altman's model and current ratio to assess the financial status of companies quoted in the Malaysian stock exchange. International Journal of Scientific and Research Publications, 2(7), 1-11.

Opler, T. C., \& Titman, S. (1994). Financial distress and corporate performance. The Journal of Finance, 49(3), 1015-1040. https://doi.org/10.1111/j.15406261.1994.tb00086.x

Pervan, I., Pervan, M., \&Vukoja, B. (2011). Prediction of company bankruptcy using statistical techniques-Case of Croatia. Croatian Operational Research Review, 2(1), 158-167.

Purnanandam, A. (2008). Financial distress and corporate risk management: Theory and $\begin{array}{llll}\text { evidence. Journal of Financial } & \text { Economics, 87(3), }\end{array}$ https://doi.org/10.1016/j.jfineco.2007.04.003

Rahimipoor, A. (2013). A comparative study of bankruptcy prediction models of Fulmer and Toffler in companies accepted in Tehran Stock Exchange. Journal of Novel Applied Sciences, 2(10), 522-527.

Uchenna, A. W., \&Okelue, U. D. (2012). Predicting Corporate Business Failure in the Nigerian Manufacturing Industry. European Journal of Business and Management, 4(10), 86-94.

Whitaker, R. B. (1999). The early stages of financial distress. Journal of Economics and Finance, 23(2), 123-132. https://doi.org/10.1007/BF02745946

Yap, B. C. F., Yong, D. G. F., \& Poon, W. C. (2010). How well do financial ratios and multiple discriminant analysis predict company failures in Malaysia. International Research Journal of Finance and Economics, 54(13), 166-175. 